\title{
CARRYOVER EFFECT OF FOMESAFEN, APPLIED ON EDIBLE BEAN, ON SUCESSIONAL MAIZE ${ }^{1}$
}

\author{
TARCÍSIO COBUCCI², JOÃO B. SILVA ${ }^{3}$ e HÉLIO T. PRATES ${ }^{3}$
}

\section{RESUMO}

\section{Efeito de resíduo no solo de fomesafen, aplicado no feijão, no milho em sucessão}

Em dois experimentos fomesafen foi aplicado em pós-emergência em culturas do feijoeiro nas doses de $0 ; 0,125 ; 0,25 ; 0,375$ e 0,5 kg/ha, em 1992 (abril e agosto) e em 1993 (março e agosto) em parcelas distintas, para avaliar os ef ei tos de se us resídu os no solo ar gi loso (Latossolo Vermelho-Escuro) na cultura do milho. O milho foi plantado em sucessão 65 e 198 dias após aplicação de fomesafen em 1992 e 65 e 212 dias em 1993. Resíduos de fomesafen no solo foram determinados por cromatografia liquida e foram detectados até $20 \mathrm{~cm}$ de profundidade, porém a maior concentração encontrada foi a $0-10$ $\mathrm{cm}$ de profundidade. Nesta profundidade, a concentração de fomesafen variou de 21 a 24 e 55 a 60 ppb aos 212 e 65 dias após aplicação de 0,25 $\mathrm{kg} \cdot \mathrm{ha}^{-1}$ de fomesafen, respectivamente, enquanto que a aplicação de $0,5 \mathrm{~kg} \cdot \mathrm{ha}^{-1}$, ap re se nt ou concentrações de 46 a 61 e 137 a 193 ppb aos 212 e 65 dias após aplicação, respectivamente. No plantio de milho aos 65 dias após aplicação de fomes afen, re síduos do he rbicida no solo reduziram o teor de clorofila na folha e volume de raiz do milho aos 10 dias após emergência. A diminuição do teor de clorofila na folha e volume de raiz, entretanto, não afetaram o rendimento de grãos.

Palavras chave: difeni1 -éter, persistência, sucessão, Phaseolus vulgaris, Zea mays.

\section{ABSTRACT}

Carryover effects of fomesafen on successional maize were studied in clay soil. Fomesafen was applied as postemergence at five rate $\mathrm{s}\left(0 ; 0.125: 0.25 ; 0.375\right.$, and $\left.0.5 \mathrm{~kg} / \mathrm{ha}^{-1}\right)$ to edible beans. Maize was planted 198 and 65 days after fomesafen application in 1992 and 212 and 65 days after fomesafen application in 1993. Fomesafen residues were detected in soils up to $20 \mathrm{~cm}$ depth but residue concentration was higher in $0-10 \mathrm{~cm}$ soil depth. Fomesafen residues reduced leaf chlrophyll content and root volume of 10 days old maize when planted 65 days after application but were not affected when planted 212 days after application. However, the decreases in le af chlorophyll and root volume did not affect the maize yield.

Key words: Diphenylether herbicide, herbicide persistence, crop rotation, Phaseolus vulgaris, Zea mays.

1Recebido para publicação em 18/04/97 e na forma revisada em 16/12/97.

2Pesquisador, Dr., Embrapa - Centro Nacional de Pesquisa de Arroz e Feijão (CNPAF), Caixa Postal 179, 74001-970 Goiania. GO. e-mail: cobucci@cnpaf.embrapa.br.

3Pesquisador, Ph.D., Embrapa - Centro Nacional de Pesquisa de Milho e Sorgo (CNPMS), Caixa Postal 151, 35701-970 Sete Lagoas, MG. 


\section{INTRODUCTION}

The Brazilian Savanna, locally known as Cerrado, is the region where grain production has been improved, has distinct dry and wet seasons. The soils have excellent physical properties but are chemically poor. It is possible to grow two crops per year with irrigation. Edible bean is $\mathrm{planted}$ from March to July, and maize in Nove mber. The herbicide fomesafen is used to control broadleaf weeds in edible bean but the effect of soil fomesafen residue on maize following edible bean is unknown.

Fomesafen is a diphenylether herbicide and its degradation in anaerobic conditions occurs in les s than 3 we eks, and in aerobic soil conditions, herbicide half-life ranged from 6 to 12 months (Johnson \& Talbert, 1993). Oymada \& Kuwatsuka (1988), studying the conditions of diphenylethers (chlornitrofen [2,4,6trichlorophenyl 4nitrophenyl ether], nitrofen [2,4 di chlorophenyl 4-nitrophenyl ether] and chlonetoxynil [2,4-dichlorophenyl 3-methoxy-4nitrophenyl ether]) degradation, reported that the half-life periods varied largely with soil conditions: 9 to 173 days for chlornitrofen, 3 to 87 days for nitrofen and 8 to 64 days for chlomethoxynil. The herbicides degrade rapidly in anaerobic conditions.

Weber (1993) reported that fomesafen exhibited weakly acidic properties. pKA $=3,0$ (ionized to anionic species as $\mathrm{pH}$ increased). Mobility, bioavailability and degradability of the herbicide fomesafen in soil is expected to be lower at low $\mathrm{pH}$ than at high or neutral $\mathrm{pH}$, due to high sorption on soil coloids.

Johnson \& Talbert (1993) determined carryover potential of fomesafen $\left(0.28 \mathrm{~kg} \cdot \mathrm{ha}^{-1}\right)$ to snap bean (Phaseolus vulgaris), watermelon (Citrullis lonatus), cucumber (Cucumis sativus), mustard (Brassica nigra) and sunflower (Helianthus annuus). The herbicide injured all crops initially, but did not injure snap bean, sunflower, watermelon and cucumber planted 16 weeks after application.

Santos (1991) applied fomesafen in edible bean and detected that the herbicide persisted until 100 days after application (DAA) of $0.25 \mathrm{~kg} \mathrm{ha}^{-1}$ and $180 \mathrm{DAA}$ of $0.375 \mathrm{~kg} \cdot \mathrm{ha}^{-1}$, using sorghum as a test crop.

We is sler \& Poole (1982) tested the application of fomesafen $\left(0.3 \mathrm{~kg} \cdot \mathrm{ha}^{-1}\right)$ in columns, and leached with $660 \mathrm{~mm}$ of water. More than $60 \%$ of the herbicide was located in the top $10 \mathrm{~cm}$, 63 DAA. In soils with $6,0 \%$ and $2,1 \%$ of organic matter, herbicide concentrations, at the same depth, were 185 and $100 \mathrm{mg} . \mathrm{dm}-3$, respectively.

The objective of the present experiment was to determine the effect of carryover fomesafen residue on leaf chlorophyll, root volume and grain yield on successional maize and to estimate the level of these residues under Brazilian Cerrado soil conditions.

\section{MATERIAL AND METHODS}

Experiments were carried out in 1992 and 1993 (one in each year) in a dark red latosol of the National Maize and Sorghum Research Center of Embrapa, Sete Lagoas, Minas Gerais, Brazil, to evaluate the soil residue effects of fomesafen on maize. The herbicide was applied on a previous edible bean crop.

Both experiments cons is ted of a $5 \times 2$ fatorial with five different rates of fomesafen $(0$; $0.125 ; 0.250 ; 0.375$ and $\left.0.5 \mathrm{~kg} . \mathrm{ha}^{-1}\right)$ and two periods of application before planting maize (65 and 198 days in 1992 and 65 and 212 days in 1993). Treatments were arranged in a split-plot design, with six replications, where the main plot 
represented fomesafen rates, and the sub-plot the two periods of application.

The soil characteristics of each experimental site are presented in Table 1. Precipitation and temperature data during the experimental period are presented in Table 2 .

TAB LE 1. Tex tural class and some che mical characteristics of the soil. Sete Lag oas, MG, Brazil, 19921993.

\begin{tabular}{ccccc}
\hline $\begin{array}{c}\text { Experiment/ } \\
\text { year }\end{array}$ & Soil texture & $\begin{array}{c}\text { Org. Mat. } \\
(\%)\end{array}$ & $\begin{array}{c}\text { CEC } \\
\left(\mathbf{C m o l}_{\mathbf{c}} \cdot \mathbf{d m}^{-3}\right)\end{array}$ & Soil pH \\
\hline $1 / 1992$ & Clay (71\% clay and 11\% sand) & 3.01 & 8.97 & 6.1 \\
$2 / 1993$ & Clay (61\% clay and 26\% sand) & 3.92 & 12.12 & 6.1 \\
\hline
\end{tabular}

" Red dark latosol.

TABLE 2. Precipitation and temperature data during crop season in Sete Lagoas, MG, Brazil, 1992-1993.

\begin{tabular}{|c|c|c|c|}
\hline Year & Month & $\begin{array}{c}\text { Precipitation }^{\mathrm{a}} \\
(\mathrm{mm})\end{array}$ & $\begin{array}{c}\text { Average } \\
\text { temperature }\left({ }^{\circ} \mathrm{C}\right)\end{array}$ \\
\hline \multirow[t]{10}{*}{1992} & Mar & 61.1 & 17.6 \\
\hline & Apr & 191.4 & 17.6 \\
\hline & May & 19.7 & 15.1 \\
\hline & June & 20.0 & 13.1 \\
\hline & July & 42.4 & 12.4 \\
\hline & Aug & 64.0 & 13.8 \\
\hline & Sept & 108.2 & 16.0 \\
\hline & Oct & 106.9 & 17.4 \\
\hline & Nov & 407.1 & 17.5 \\
\hline & Dec & 133.6 & 18.1 \\
\hline \multirow[t]{10}{*}{1993} & Mar & 61.2 & 17.9 \\
\hline & Apr & 138.1 & 17.3 \\
\hline & May & 83.5 & 13.5 \\
\hline & June & 27.4 & 11.9 \\
\hline & July & 50.0 & 12.0 \\
\hline & Aug & 103.8 & 12.9 \\
\hline & Sept & 10.5 & 16.2 \\
\hline & Oct & 102.6 & 17.0 \\
\hline & Nov & 187.6 & 18.3 \\
\hline & Dec & 230.8 & 18.7 \\
\hline
\end{tabular}

\footnotetext{
Rain + irrigation.
} 
Edible bean was planted on March, 18 and July, 27, in each sub-plot, respectively, and the herbicide fomesafen was applied on April, 7 and Augu st, 8 in 1992 with a CO2 -pressurized backpack sprayer delivering 2501 ha $^{-1}$ at 275 $\mathrm{kPa}$. In 1993, edible bean was planted on March, 2 and July, 16, in each sub-plot and herbicide was applied on March, 22 and August, 16.

Fomesafen residue: Chemical analysis of soil fomesafen residue were performed in the second year (1993), in the plots which received 0.25 and $0.5 \mathrm{~kg} . \mathrm{ha}^{-1}$ of fomesafen. Soil samples composed of five subsamples taken at 0 to 5,5 to 10 and 10 to $20 \mathrm{~cm}$ deep 29, 64, 136, 189 and 232 DAA in the plots where fomesafen was applied 212 days before maize and 42 and 85 DAA in the plots where it was applied 65 days before maize. Fomesafen residue was extracted by shaking $20 \mathrm{~g}$ of soil with $100 \mathrm{ml}$ of acetonitrile: hydrochloric acid (98:2), for $30 \mathrm{~min}$ in a horizontal shaker. The extract was filtered through a celite pad under vacuum. Residue was washed with $50 \mathrm{ml}$ of acetonitrile. The extract $(70 \mathrm{ml})$ - water $(100 \mathrm{ml})$ mixture was transferred to a separatory funnel and shaken for $3 \mathrm{~min}$ with $100 \mathrm{ml}$ of dichloromethane, and the lower phase (dichloromethane) was collected. This procedure was repeated with an additional $50 \mathrm{ml}$ of dichloromethane. The combined dichloromethane extracts we re evaporated to dryness at $35 \mathrm{C}$ on a rotary evaporat or. The residue was taken up in chloroform $(3 \mathrm{ml})$ and passed through a silica adsorption column chromatography. The elute was evaporated to dryness and taken up with $1 \mathrm{ml}$ of acetonitrile: water ( $\mathrm{pH}$ 2.5) 50:50. The amount of fomesafen was determined with a high performance liquid chromatography. The analytical conditions were: Shim-pach CLC-ODS (M), reverse-phase, with $4.6 \mathrm{~mm} \times 25 \mathrm{~cm}$ in stainless steel and $5 \mathrm{~mm}$ pore diameter, column temperature of $40^{\circ} \mathrm{C}$, mobile phase acetonitrile:water ( $\mathrm{pH} 2.5$ ) 50:50, flow rate of 2.0 ml.min-1, UV detect or at $290 \mathrm{~nm}$ wavelength, sample amount of $20 \mathrm{ml}$. A linear calibration curve was constructed using known fomesafen

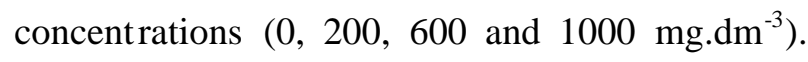
The solutions of known concentration consisted of analytical herbicide (chemical purity $>99 \%$ ). The concentration of fomesafen in soil sample extracts was determined by entering peak area values into a regression equation describing the calibration curve. Fomesafen recovery from soil samples was $100 \%$. The lower limit for detection of fomesafen in soil samples was $5 \mathrm{mg} \cdot \mathrm{dm}^{-3}$

\section{Effect of fomesafen residue on maize:} Maize cultivars, Cargill 805, were sown on October, 22 in 1992 and BR 201 on October, 20 in 1993 in $90 \mathrm{~cm}$ rows, using 65.000 seeds ha' and were mown 30 days after emergence. The seedling emergence, leaf chlorophyll concentration and root volume were meas ured 10 days af te $r$ emergence. Chlorophyll concentration was estimated by Arnon's method (Arnon, 1949). The samples were taken at the middle portion of the first leaf of 10 plants per plot. The roots were washed and plunged in to graduated tubes containing $50 \mathrm{ml}$ of water to determine root volume by water volume difference. Maize grain yield was estimated using the two center rows of each plot and adjusted to $13 \%$ of moisture.

\section{RESULTS AND DISCUSSION}

Fomesafen residue: Average data for fomesafen concentrations in the soil are presented in Table 3. For both periods of fomesafen application before maize (212 and 65 days), the ANOVA showed significant main effects for 
fome sa of en rate, soil depth and DAA. A significant interaction between depth and DAA was observed. Based on these results, the study

TABLE 3. Fomesafen residue $\left(\mu \cdot \mathrm{g} \cdot \mathrm{dm}^{-3}\right)$ as affected by rate of application, depth $(\mathrm{cm})$ and days after application (DAA) in two application dates before maize, Sete Lagoas, MG, Brazil, 1993. was carried out using the average fomesafe $n$ rate $\left(0.25\right.$ and $\left.0.5 \mathrm{~kg} \cdot \mathrm{ha}^{-1}\right)$.

\begin{tabular}{|c|c|c|c|c|c|c|c|}
\hline \multirow{3}{*}{$\begin{array}{l}\text { Application } \\
\text { before } \\
\text { maize (days) }\end{array}$} & \multirow[t]{3}{*}{ DAA } & \multicolumn{6}{|c|}{ Fomesafen residue } \\
\hline & & \multicolumn{3}{|c|}{$0.25 \mathrm{~kg} \cdot \mathrm{ha}^{-1}$} & \multicolumn{3}{|c|}{$0.5 \mathrm{~kg} \cdot \mathrm{ha}^{-1}$} \\
\hline & & 0 to 5 & 5 to 10 & 10 to 20 & 0 to 5 & 5 to 10 & 10 to 20 \\
\hline & & \multicolumn{6}{|c|}{ - } \\
\hline \multirow[t]{5}{*}{212} & 29 & 209 & 77 & $<5$ & 281 & 93 & 41 \\
\hline & 64 & 83 & 42 & $<5$ & 157 & 95 & 54 \\
\hline & 136 & 66 & 90 & 21 & 128 & 103 & 38 \\
\hline & 189 & 40 & 41 & $<5$ & 63 & 18 & 27 \\
\hline & 232 & 21 & 24 & $<5$ & 46 & 61 & 11 \\
\hline \multirow[t]{2}{*}{65} & 42 & 134 & 34 & 32 & 188 & 135 & 49 \\
\hline & 85 & 55 & 60 & 12 & 137 & 193 & 40 \\
\hline
\end{tabular}

When the herbicide was applied 212 and 65 days before maize, a significant decrease of its soil concentration 0 to $5 \mathrm{~cm}$ deep was observed as DAA increased (Figures la and $1 \mathrm{~b}$ ). This was probably due to microbial decomposition. Acc or ding to Johns on \& Talbert (1993), fomesafen dissipation in the soil occurs mainly by microbial degradation. Oymada \& Kuw atsuka (1988) reported that diphenylether herbicides are degraded faster under reductive than oxidative conditions, and that there are many micoorganisms in the soil which reduce the nitro group of such herbicides.

In Figures $1 \mathrm{a}$ and $\mathrm{lb}$, it can be observed that fomesafen residue concentrated more at 0 to $10 \mathrm{~cm}$ in the soil profile. Weissler \& Poole (1982) observed that 63 DAA $\left(0.3 \mathrm{~kg} \cdot \mathrm{ha}^{-1}\right.$ of fomesafen) in a loamy sandy soil (2.1\% O.M.) and with $660 \mathrm{~mm}$ of precipitation, $60 \%$ of fomesafen 


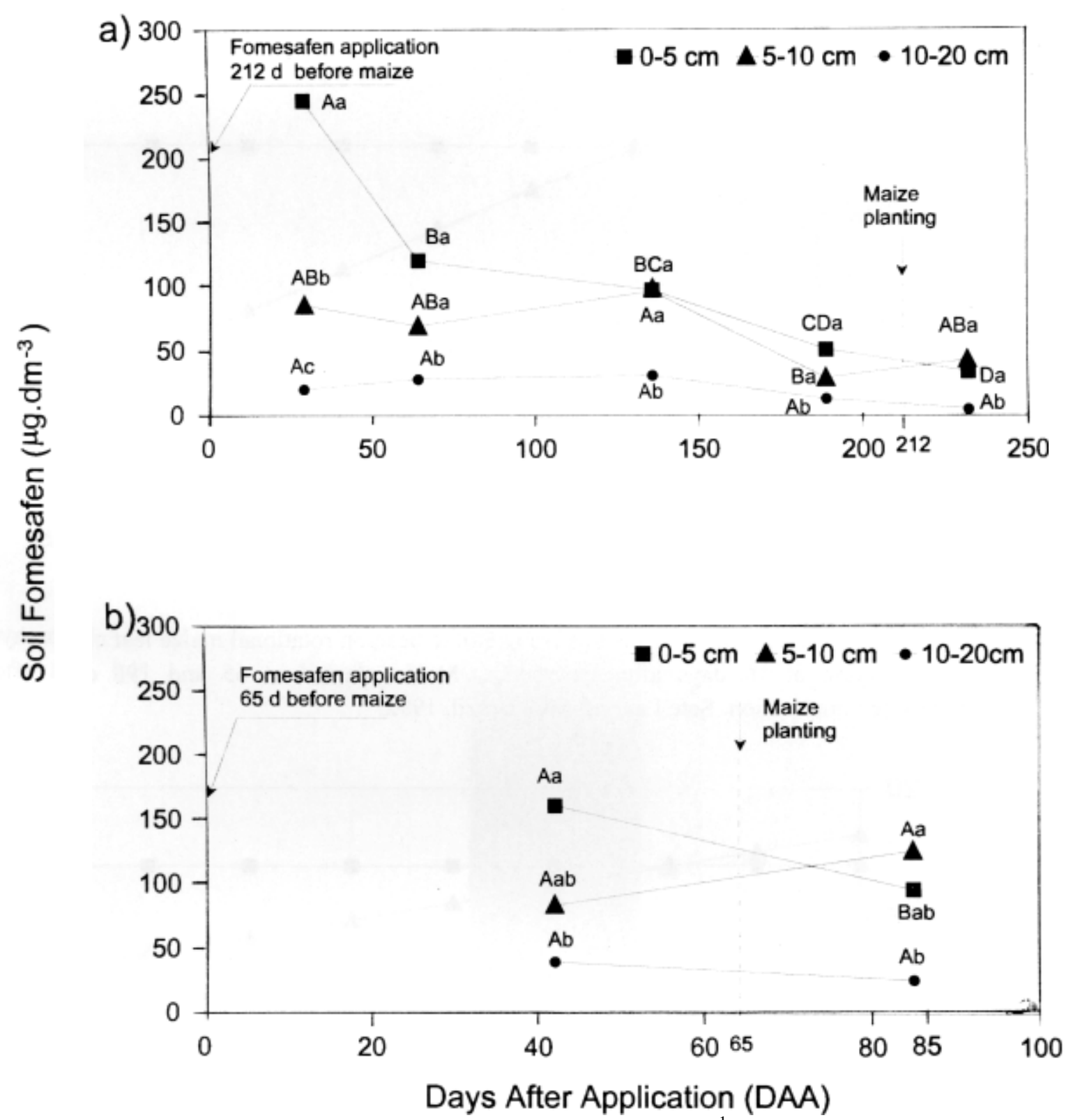

FIGURE 1. Soil fomesafen residue (means of 0.25 and $0.5 \mathrm{~kg}^{-} \mathrm{ha}^{-1}$ rates) as affected by DAA at three depths and two application dates. Means followed by the same letter are not significantly different according to Tukey's test at 0.05 level of probability. Capital letters were used to compare means among DAA for any depth and small letters to compare means among depths for any DAA. Sete Lagoas, MG, Brazil, 1993.

Effect of fomesafen residue on maize: In 1992, when the interval between fomesafen application and maize planting was 65 days, the leaf chlorophyll concen tration and root volume, measured 10 days after emergence, decreased with increased fomesafen rates (Figures
2 and 3). There was no significant difference among the fomesafen rates concerning concentrations determined - 198 DAA. Santos (1991) detected fomesafen residue until 180 DAA, using sorghum as a test crop. 
Carryover effect of fomesafen, applied on edible bean, on sucessional maize.

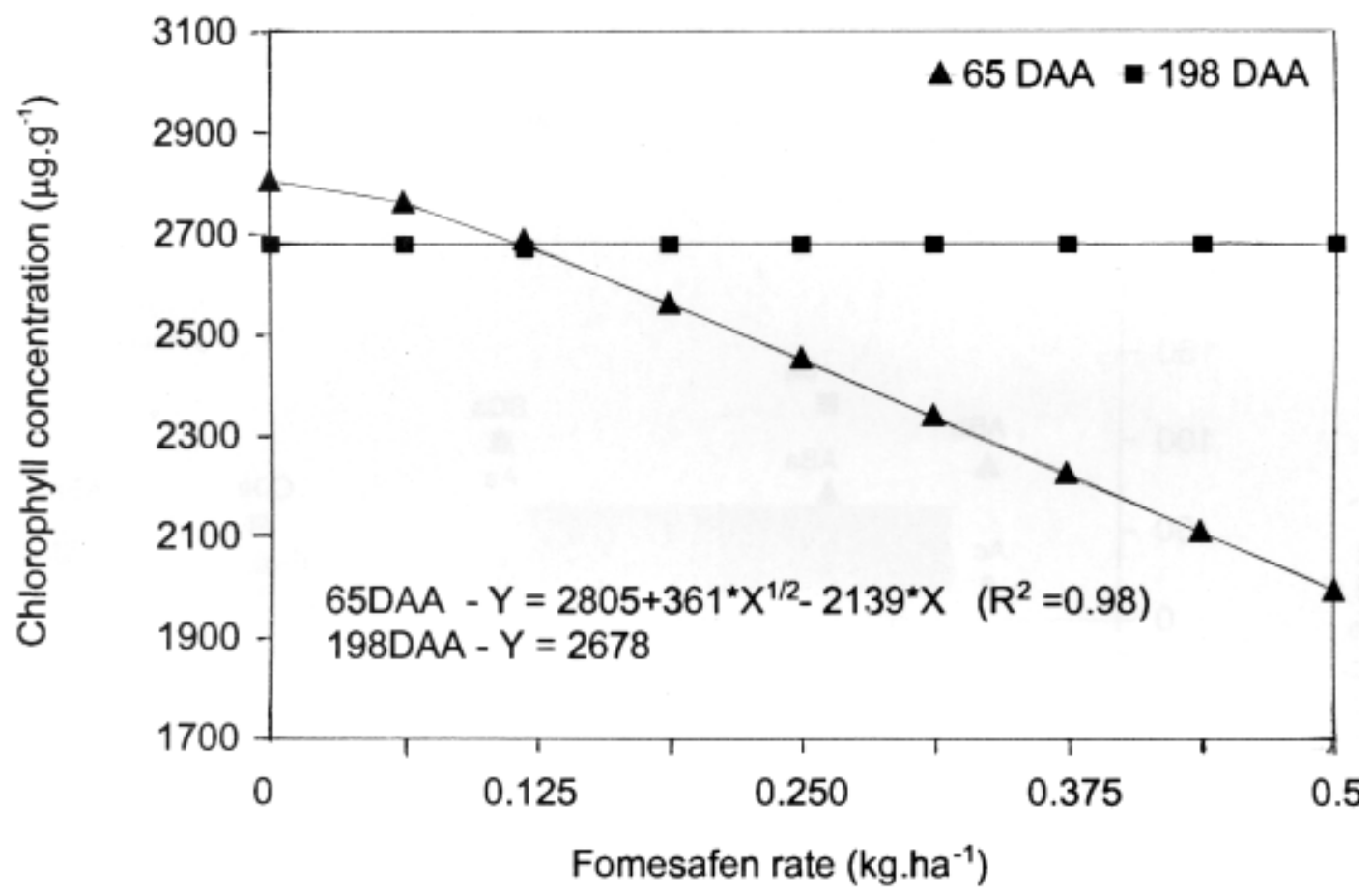

FIGURE 2. Effect of fomesafen carryover residue from edible bean on rotational maize leaf chlorophyll concentration at 10 days after emergence. Maize planted at 65 and 198 days after fomesafen application. Sete Lagoas, MG, Brazil, 1992.

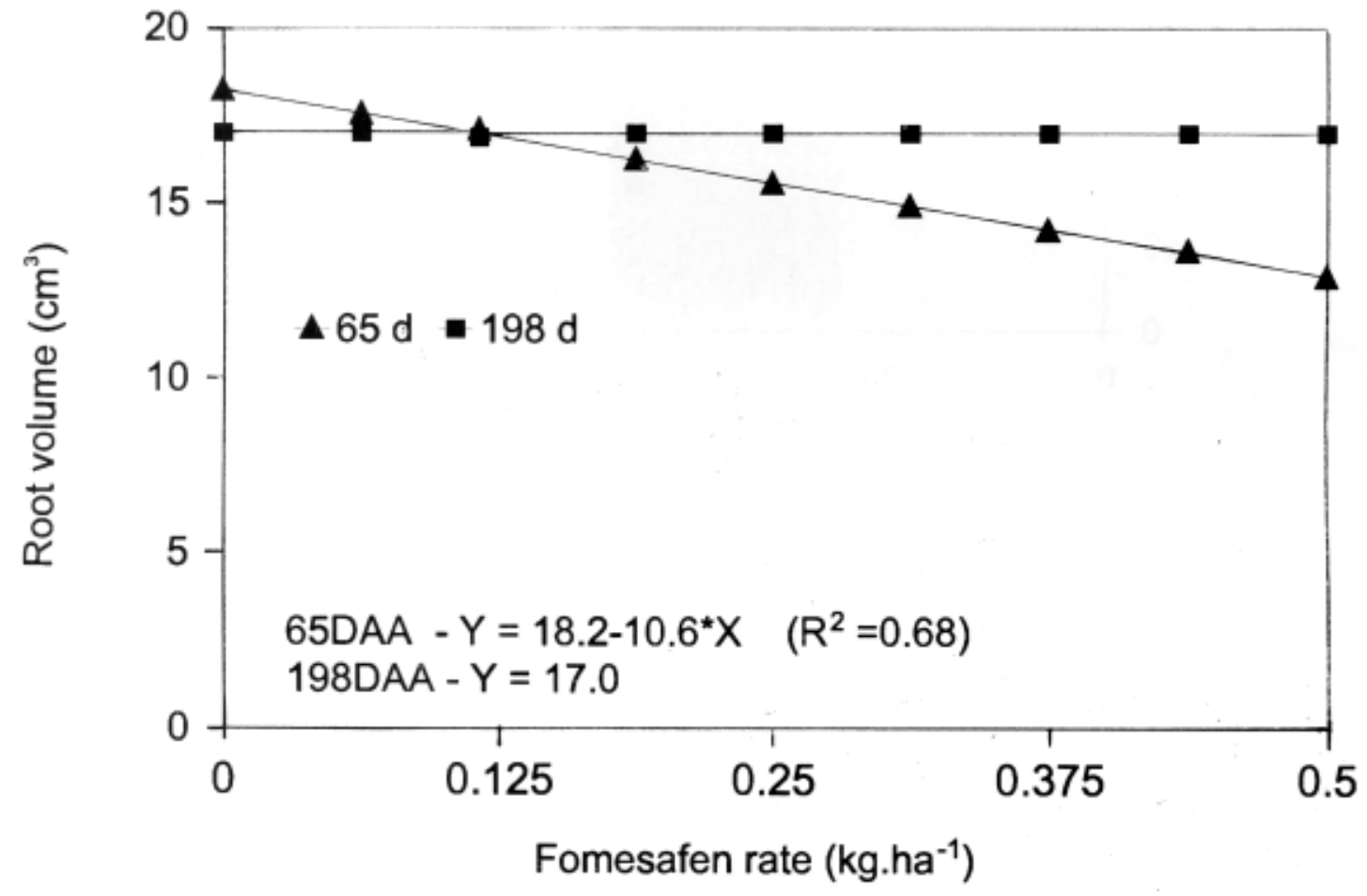

FIGURE 3. Effect of fomesafen carryover residue from edible bean on rotational maize root volume at 10 days after emergence. Maize planted at 65 and 198 days after fomesafen application. Sete Lagoas, MG, Brazil, 1992. 
The decrease of leaf chlorophyll concentrations related to fomesafen residue in the soil can be explained by the protoporphyrinogen oxidase inhibition (enzyme in chlorophyll synthe si s path way). Then, non-en zy matic oxidation occurs, which forms protoporphyrin IX that interacts with oxygen and light, resulting in singlet oxygen forms. The non-enzymatic protoporphyrin IX is not an acceptable substrate for $\mathrm{Mg}$ chelatase and contributes to the decrease in chlorophyll synthesis (Weller \& Warren, 1992). The yellow stripes that appear on the leaves are the main symptom of fomesafen residue effect on maize. This may be due to decrease in chlorophyll concentration.

The ANOVA did not show significant effect for fomesafen rate and period of application for maize yield,. indicating that despite residue damage to maize plants observed 10 days after emergence, the crop is capable to recover with no negative effects on yield. One explanation for the symptoms observed in the initial stage of maize development may be due to the fact that, at that time, roots were exploring the soil profile where fomesafen residue was more concentrated ( 0 to 10 $\mathrm{cm}$ ), inducing the appearance of yellow stripes on the leaves. In later stages of plant growth, with deeper root proliferation, effects of fomesafen residue were overcome. It is import ant to notice that initial stand of maize was not affected by soil fomesafen residue. Seedlings death did not occur even with the highest rates of fomesafen $(0.5 \mathrm{~kg}$. $\mathrm{ha}^{-1}$ ) or with the smallest interval between fomesafen application and maize planting (65 days). In 1993, within the same time range period (65 days), a significant decrease in leaf chlorophyll concentration and root volume of maize was observed 10 days after emergence with increasing fomesafen rates (Figures 4 and 5). These results are in accordance with those found in the previous year (1992), confirming the negative effect of fomesafen residue on initial stages of maize growth. As in 1992, fomesafen residue did not affect maize yield significantly.

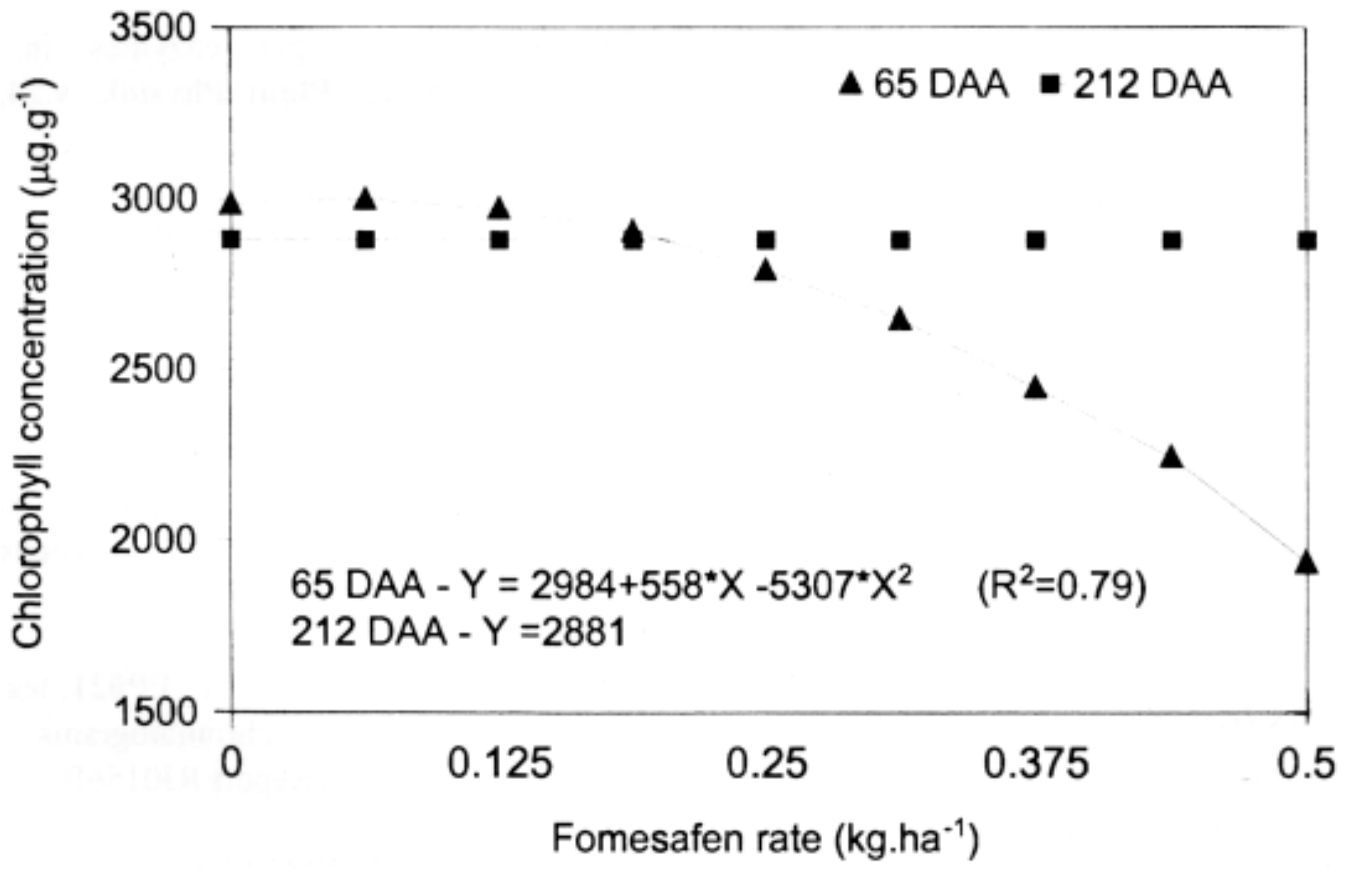

FIGURE 4. Effect of fomesafen carryover residue from edible bean on rotational maize leaf chlorophyll concentration at 10 days after emergence. Maize planted at 65 and 212 days after fomesafen application. Sete Lagoas, MG, Brazil, 1993. 


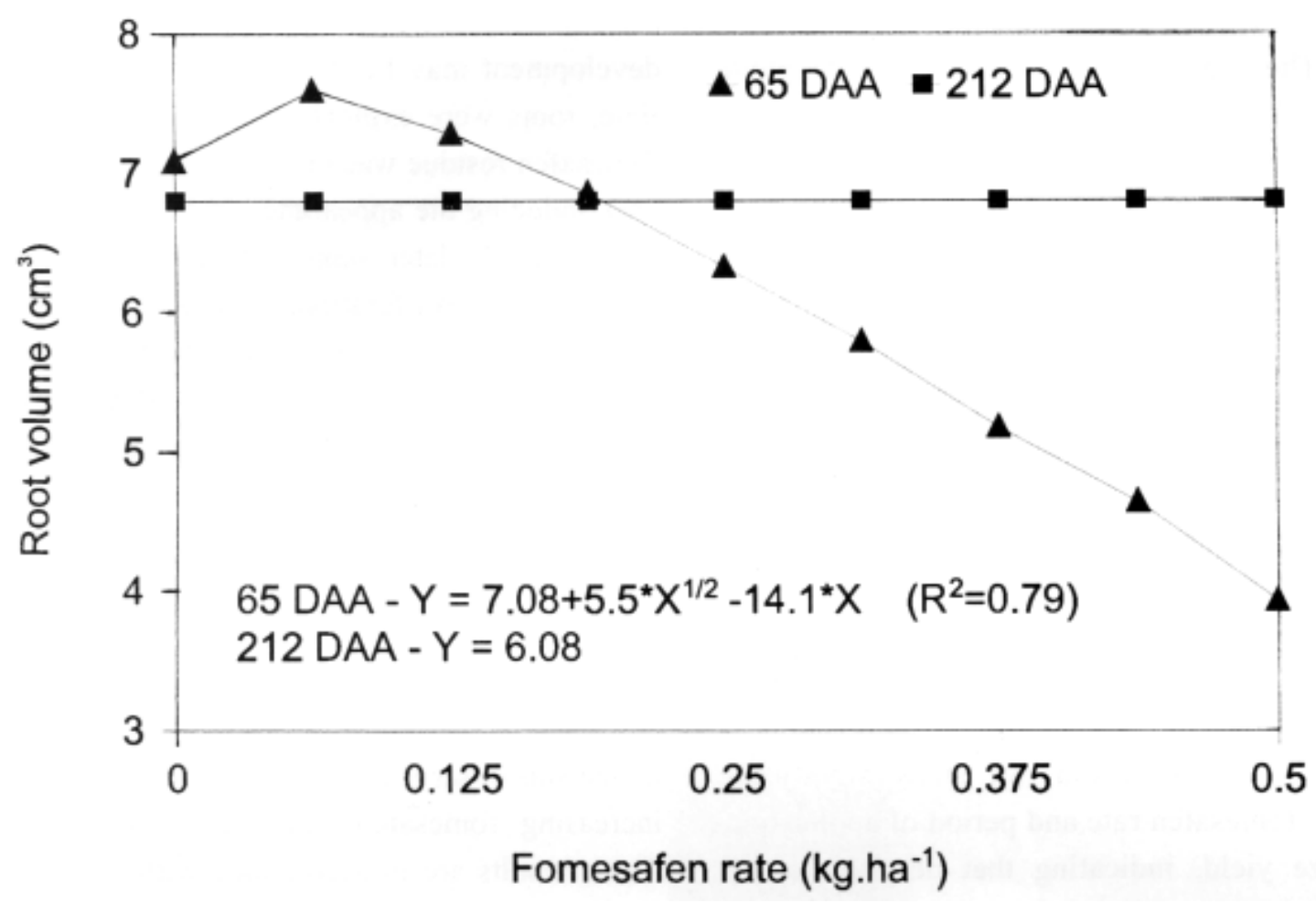

FIGURE 5. Effect of fomesafen carryover residue from edible bean on rotational maize root volume at 10 days after emergence. Maize planted at 65 and 212 days after fomesafen application. Sete Lagoas, MG, Brazil, 1993.

The results obtained in this study demonstrated that fomesafen application in edible bean crop, at the recommended rate of $0.25 \mathrm{~kg}_{\mathrm{gha}}{ }^{-1}$, did not affect maize yield, even when the interval betwe en application and maize planting was 65 days. Nevertheless, it is worth to point out that the persistence of herbicides in the soil may vary according to several factors, such as soil type, precipitation and temperature. On this basis, data presented here should be considered according to the test conditions.

\section{ACKNOWLEDGMENTS}

We th an $\mathrm{k}$ Zeneca Brazil for partial financial support of this study.

\section{LITERATURE CITED}

ARNON, D. I. Cooper enzymes in is ol ated chloroplasts. Plant Physiol., v.24, p.1-15, 1949.

HINGSTON, F.J., POSNER, A.M., QUIRK, J.P. Anion sorption by goethite and gibbsite. J. Soil Sci., v.23, p.177-192, 1972.

JOHNSON, D.H., TALBERT, R.E. Imazaquin, chlorimuron, and fomesafen may injure rotational ve getables and sunflower (Helianthus annuus). Weed Technol., v.7, p.573-5T7, 1993.

NEWBY, S.E., WHITE, B.G. PP021: leaching on soil thick-layer chromatograms. London, ICI, 1981. 4p. (Report RJ0156B).

OYMADA, M., KUWATSUKA, S. Effects of soil properties and conditions on the degradation fo three diphenylether 
herbicides in flooded soils. J. Pestic. Sci., v.13, p.99-105, 1988.

SANTOS, J.G.M. Controle químico de plantas daninhas na cultura do feijão (Phaseolus vulgaris $L$.), no inverno. Viçosa, UFV, 1991. Tese de Mestrado.

TISDALE, S.L., WERNER, S.L., BEATON, J.D. Basic soil-plant relationships. In: TISDALE, S.L., WERNER, S.L., BEATON, J.D. Soil fertility and fertilizers. 4.ed. New York, Macmil lan Publishing Co., 1985. p.95-111.

WEBER, J.B. Ionization and so rption of fomesafen and atrazine by soils and soil constituents. Pestic. Sei., v.39, p.3138, 1993.

WE ISSL ER, M.S., PO OL E, N.J. Mobility of fomesafen and degradation products in so il colu mn s. Lond on, IC I, 1982.3p. (Report RJ0241 B).

WELLER, S.C., WARREN, G.F. Diphenylethers and oxadiazon. In: WELLER, S.C., WARREN, G.F. Herbicide action course. West Lafayette, Purdue University, 1992. p.113-120. 